\title{
Training Background and Early Retirement
}

Citation for published version (APA):

Montizaan, R., Corvers, F., \& De Grip, A. (2008). Training Background and Early Retirement. IZA. IZA Discussion Paper Series No. 3504

Document status and date:

Published: 01/01/2008

Document Version:

Publisher's PDF, also known as Version of record

\section{Please check the document version of this publication:}

- A submitted manuscript is the version of the article upon submission and before peer-review. There can be important differences between the submitted version and the official published version of record.

People interested in the research are advised to contact the author for the final version of the publication, or visit the DOI to the publisher's website.

- The final author version and the galley proof are versions of the publication after peer review.

- The final published version features the final layout of the paper including the volume, issue and page numbers.

Link to publication

\footnotetext{
General rights rights.

- You may freely distribute the URL identifying the publication in the public portal. please follow below link for the End User Agreement:

www.umlib.nl/taverne-license

Take down policy

If you believe that this document breaches copyright please contact us at:

repository@maastrichtuniversity.nl

providing details and we will investigate your claim.
}

Copyright and moral rights for the publications made accessible in the public portal are retained by the authors and/or other copyright owners and it is a condition of accessing publications that users recognise and abide by the legal requirements associated with these

- Users may download and print one copy of any publication from the public portal for the purpose of private study or research.

- You may not further distribute the material or use it for any profit-making activity or commercial gain

If the publication is distributed under the terms of Article $25 \mathrm{fa}$ of the Dutch Copyright Act, indicated by the "Taverne" license above, 


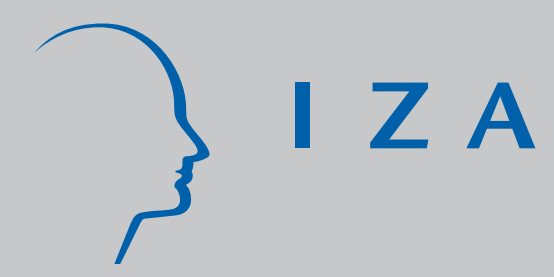

IZA DP No. 3504

Training Background and Early Retirement

Raymond Montizaan

Frank Cörvers

Andries De Grip

May 2008 


\title{
Training Background and Early Retirement
}

\author{
Raymond Montizaan \\ ROA, Maastricht University \\ Frank Cörvers \\ ROA, Maastricht University \\ Andries De Grip \\ ROA, Maastricht University \\ and IZA
}

\section{Discussion Paper No. 3504 \\ May 2008}

\author{
IZA
}

P.O. Box 7240

53072 Bonn

Germany

Phone: +49-228-3894-0

Fax: +49-228-3894-180

E-mail: iza@iza.org

\begin{abstract}
Any opinions expressed here are those of the author(s) and not those of IZA. Research published in this series may include views on policy, but the institute itself takes no institutional policy positions.

The Institute for the Study of Labor (IZA) in Bonn is a local and virtual international research center and a place of communication between science, politics and business. IZA is an independent nonprofit organization supported by Deutsche Post World Net. The center is associated with the University of Bonn and offers a stimulating research environment through its international network, workshops and conferences, data service, project support, research visits and doctoral program. IZA engages in (i) original and internationally competitive research in all fields of labor economics, (ii) development of policy concepts, and (iii) dissemination of research results and concepts to the interested public.
\end{abstract}

IZA Discussion Papers often represent preliminary work and are circulated to encourage discussion. Citation of such a paper should account for its provisional character. A revised version may be available directly from the author. 
IZA Discussion Paper No. 3504

May 2008

\section{ABSTRACT}

\section{Training Background and Early Retirement ${ }^{*}$}

Several studies show that employees with firm-specific skills are more likely to be covered by employer-sponsored pension schemes than workers with general skills. Therefore it can be expected that workers with firm-specific skills retire earlier. This paper tests this prediction using US data from the National Longitudinal Survey of Older Men. We find that workers who participated in firm-specific training in their early careers retire earlier than workers with a general training background. This indicates that shared investments in firm-specific training are embedded in implicit contracts that induce early retirement. The results remain robust when controlling for technological change and work commitment.

JEL Classification: J14, J26, J31

Keywords: retirement, training, deferred compensation

Corresponding author:

Raymond Montizaan

ROA

Maastricht University

P.O. Box 616

6200 MD Maastricht

The Netherlands

E-mail: r.montizaan@roa.unimaas.nl

\footnotetext{
*We are indebted to Lex Borghans, Didier Fouarge, Daniel Hamermesh, Ben Kriechel, Pierre Mohnen, Gerhard Pfann, Jan Van Ours and Maarten Vendrik for their valuable comments. We thank Ann Bartel, Nachum Sicherman and Dale Jorgenson for providing us with the industry measures of productivity growth. Any remaining shortcomings are the responsibility of the authors.
} 


\section{Introduction}

Human capital theory predicts that firms enter into implicit contracts with new hires in order to ensure rent sharing and to decrease turnover after firm-specific training investments. From Johnson (1996) and Dorsey and Macpherson (1997) it follows that these implicit contracts may include defined benefit pensions. Oppositely, firms are indifferent to turnover of employees with a perfectly general training background because workers with general skills are paid equal to the value of their marginal product when the labor market is perfectly competitive. Therefore, firms do not provide pension coverage to workers with general skills. These differences in the treatment of workers with firm-specific and general skills may have large consequences for retirement patterns.

In this paper, we contribute to the existing life-cycle literature by directly estimating the impact of workers' firm-specific and general training background on the likelihood of early retirement. By using the slightly adapted training indicators of Johnson (1996), we are able to increase insights in the causality between training background and retirement behavior. The long period between training participation and the retirement date in our analyzes minimizes the likelihood that workers anticipated on retirement when they made their decisions to train. Moreover, we control for the effects of technological change on retirement, business cycle effects and workers' retirement preferences.

The paper is related to the literature on the relationship between deferred compensations and the preservation of human capital investments. The central starting point of this literature is the bilateral monopoly problem between the employee and employer after firm-specific investments which leads to undesirably high turnover of employees (Kennan, 
1979; Johnson, 1996; Fella, 2005). To circumvent this problem, deferred compensation in the form of pension coverage can be used as an instrument to decrease turnover (Kennan, 1979; Johnson, 1996; Dorsey and Macpherson, 1997). ${ }^{1}$ The latter studies found that firm-specific training has a larger effect on pension coverage than general training. Because pension coverage induces early retirement (see Stock and Wise, 1990; Samwick, 1998; Bingley and Lanot; 2002; Chan and Stevens, 2004), the straightforward implication is that workers with firm-specific skills will retire earlier than workers with general skills who are less likely to be covered by a employers pension system. However, in economic literature, there are no empirical studies on the relationship between employees' training background and early retirement.

We find, consistently with human capital theory, that workers who received firmspecific training in their early careers retire earlier than workers with a general training background. These findings are robust when controlling for technological change and work commitment and when correcting for job mobility. This indicates that shared investments in firm-specific training are embedded in implicit contracts that aim at decreasing turnover but also induces early retirement.

This paper is organized in six sections. In the next section, we will discuss our theoretical framework. The data is described in Section 3. In Section 4, we present our estimation method. In Section 5, we will estimate the impact of workers' training history on retirement behavior. Summarizing conclusions are given in Section 6 . 


\section{Theory: Training investments, backward loading earning profiles and early retirement}

We consider an economy in which two types of training exist (Becker, 1975): general training and firm-specific training. General training increases workers productivity independently of the firm where they are employed. Following human capital theory, we assume that the costs of training skills that are perfectly transferable to other firms will be borne by the worker. Because there is a substantial risk that these workers will leave the current firm, workers will pay for the training by accepting lower wages during the time that they participate in a training course and are paid accordingly to the value of their marginal product. Therefore, firms are indifferent to turnover and retirement of workers with perfectly general skills (Dorsey and Macpherson, 1997).

Workers who participated in firm-specific training, however, have human capital that is valuable to the firm where they work for, but not to other firms. This makes firms willing to share the costs of firm-specific training by paying workers a wage that exceeds the value of their marginal product during the period in which firm-specific training investments are made. After the training investment, the rents of the firm-specific training are shared by the employer and the employee. ${ }^{2}$ Both parties will only benefit from the training investment when the employment relationship is to be continued.

However, Kennan (1979), Johnson (1996) and Fella (2005) stated that a bilateral monopoly problem may arise after a workers' participation in firm-specific training. Any rent-sharing rule remains vulnerable to threats to terminate the contract by either side. These threats to terminate the contract arise because workers as well as firms have an 
incentive to extract extra rent from the other party. The inability of firms to bind their workers results in a risk that they are not able to fully reap the rents of the training investment.

Informal bonding can be used as an instrument to prevent bilateral monopoly problems and to decrease turnover of workers with firm-specific skills (Kennan, 1979; Johnson, 1996; Dorsey and Macpherson, 1997). ${ }^{3}$ In the context of firm-specific training investments, deferred compensation can be seen as a bond to compensate employers for quitting while the obligation to pay severance pay in the case of a layoff can be seen as a bond to compensate the workers. With deferred compensation, workers are paid less than their value of marginal productivity when they are young and they are paid more when they become older. This gives workers an incentive to stay with the firm as they will earn high future earnings relative to the wage they are able to earn elsewhere. Therefore, deferred compensation induces lower turnover and ensures the rent earnings for firms after firm-specific human capital investments.

Several studies found that defined benefit pensions sponsored by companies is an efficient and commonly used way of deferring future compensation in order to reduce turnover and training costs (e.g. Gustman et al, 1994; Williamson, 1995; Johnson, 1996; Dorsey and Macpherson, 1997). Due to the tax preferred status of pensions and the progressivity of income taxes, many workers wish to participate in company sponsored pension plans (Gustman et al., 1994). Firms are willing to provide pension coverage because it enables the early disposal of older workers with firm-specific skills in case of unanticipated changes in productivity due to technological change or in market wage rates. The relationship between pension coverage and general and firm-specific training has been 
further studied by Dorsey and Macpherson (1996) and Johnson (1997) who found a strong positive relationship between pension coverage and training. The latter study found that firm-specific training has a larger effect on pension coverage than general training.

The differences in pension coverage for workers with firm-specific and general skills may have large consequences for retirement patterns. Studies which assessed the effects of pensions on the retirement age indicate that workers with generous pensions retire earlier than those with lower or no pension benefits (e.g. Stock and Wise, 1990; Samwick, 1998; Bingley and Lanot; 2002; Chan and Stevens, 2004). However, Bingley and Lanot (2002) found that employer-specific compensation has only a profound effect on retirement flows when access to public transfers is limited. ${ }^{4}$ Nevertheless, the higher pension coverage of workers with firm-specific skills relative to workers with general skills in combination with the negative effect of pensions on the retirement age suggests that workers with firm-specific capital will retire earlier than workers with general skills or workers who did not participate in training. ${ }^{5}$

\section{Data}

The effect of training on early retirement is estimated using data from the US National Longitudinal Survey of Older Men (NLSOM). The NLSOM is a nationally representative survey of 5,020 men in 1966 between the ages of 45 and 59 who were questioned periodically until 1983. Individuals were interviewed 12 times with 1- and 2-year intervals. The NLSOM is a rich longitudinal dataset with detailed information on employment history, health limitations, demographics and personal characteristics. 
During each interview, respondents were asked about their major activity during the survey week. Based on this variable, we limit our analysis to workers who were not self employed. ${ }^{6}$ Retirement status was determined for those who answered for the first time that they were retired. Approximately $49 \%$ of the workers in our sample retired between 1966 and 1983. In 1983, 1,554 workers reported that they were retired, 434 individuals were still working and 127 individuals workers were not able to work. 1,582 workers died before 1983. Interestingly, the majority of the workers retired before the institutional mandatory retirement age of 65 years (average retirement age is 63 years). ${ }^{7}$ Only $15 \%$ of the workers retired before they reached the age of 60 .

Human capital development is influenced by participation in formal and informal training. Based on the NLSOM, we are only able to analyze the formal training element. Our training indicators are based on the in 1966 asked question, if respondents ever received formal training. More specifically, questions were asked on participation in vocational training (excluding on-the-job training), the type and duration of vocational training, whether respondents used the skills acquired through training on the current or last job and who sponsored the longest vocational training program.

The training information of the 1966 wave is used to construct two dummy variables analogous to Johnson (1996). Using the training history prior to 1966 implies that there is a sufficiently long period between training participation and retirement, reducing possible causality issues between our measures for training investments and retirement. ${ }^{8}$ Both dummy variables are based on the longest vocational training program. The first variable serves as an indicator for firm-specific training history and equals 1 if workers had ever received company-sponsored training and still benefit from this training in their current 
job. The second dummy variable is a proxy for general training and equals 1 if workers had ever received other training such as course work at universities or technical institutes. Possibly, the incidence of specific training is overstated. Pre-1966 training may have been completed on a previous job, which may imply that the formerly acquired skills are not specific to the present job. However, by restricting training participation in the training indicators to people who still use the acquired training in their current job, we partially account for the overstatement of the incidence of specific training. ${ }^{9}$

In our analysis, we control for the effects of skills depreciation. Information on individual skills depreciation is not available in the NLSOM. Therefore, the rate of technological change per industry in which individuals are employed will be used as a proxy for skills depreciation. The technological change variables are based on the rates of industry productivity change calculated by Jorgenson et al. (1987) for 35 industry sectors. ${ }^{10}$ Technological change is measured as the rate of change in productivity that is not accounted for by growth in the quantity and quality of physical and human capital. In a seminal paper, Bartel and Sicherman (1983) showed that it is relevant to make a distinction between the effects of gradual technological change and technological shocks on retirement. We have replicated their two technological change variables. The first variable is measured by the mean annual rate of technological change over the 10 -year period before period $t$, which characterizes the long run differences in technological change between industries. The second variable is measured by the unexpected change in the rate of technological change, which is defined as a z-score.

Other control variables in our analysis that deserve some attention are health status and job tenure. The health variable is a lagged variable that is constructed from answers to 
questions on the limitations of health in the working situation. Here, the health limitations variable is coded 1 if the individuals' health limits work and coded 0 otherwise. In noninterview years, we assume that individuals had the same health limitations as in the preceding year. For 1968, we use the answers to the questions on health change (health change compared to the previous year) and the effects of the health change on limitations at work. Job tenure is measured by using answers on questions on job tenure or the year they started working in the current or last job.

Lastly, we include four variables in our analysis to control for business cycle effects and retirement preferences: unemployment rate, output growth, a work commitment variable and one year lagged self reported yearly wages (in logs). The unemployment rate and output growth indicators are included to account for changes in the business cycle. The unemployment rate is measured for the civilian non-institutional population of 16 years and older and is based on BLS Household Annual Averages data. Output growth, like the technological change indicators, have been divided into two different variables indicating the gradual change and shock in output growth. Similar to Bartel and Sicherman (1993), the Jorgenson database is used for our indicators of output growth. The indicators have been calculated in the same way as the technological change indicators. The work commitment variable is added in our analysis to account for job motivation and retirement preferences of employees. The work commitment variable is based on the 1966 question whether respondents would stop or continue working, if they got enough money to live comfortably. In this study, work commitment is coded 1 if workers replied that they would continue to work and 0 if they were undecided or answered that they would stop working. We assume that workers who indicated that they would continue to work, 
derive less utility of leisure than workers who indicated to stop working. Higher yearly wages may also contribute to earlier retirement as workers with higher earnings are likely to have more savings. ${ }^{11}$

\section{Insert Table 1 about here}

Sample means and standard deviations of selected variables are given in Table 1. The table shows that approximately $4 \%$ of all the workers has a firm-specific training background, while $19 \%$ has a general training history. The mean gradual technological change is rather low with $0,6 \%$. On average, the workers in our sample are relatively low educated (average is 9 years of education). Workers have an average tenure level of 15 years, are 51 years old in 1966 and are largely committed to their work (75\%). 84\% of the men in our sample is married, $32 \%$ is non-white and $35 \%$ has health problems.

\section{Method}

The determinants of retirement behavior of workers can be modelled in hazard regression models. The hazard function analyzes the probability of entering retirement at a certain age $t$, conditional on that individuals do not retire before that age, and can be denoted as:

$$
h(t)=\lim _{d t \rightarrow 0} \frac{\operatorname{Pr}(t \leq T<t+d t \mid T \geq t)}{d t}=\lim _{d t \rightarrow 0} \frac{F(t+d t)-F(t)}{d t S(t)}=\frac{f(t)}{S(t)}
$$


where $T$ is a random variable with a continuous probability distribution $f(t)$, where $t$ is the realization of $T$ (retirement). $S(t)$ is the survival function which gives the probability that the spell in which workers remain working is at least $t$. To estimate the effect of training and technology on retirement behavior, we use a parameterized proportional hazard model with a Weibull distribution. ${ }^{12}$ The Weibull hazard function and survival function are:

$$
h(t)=p \lambda t^{p-1}
$$

$$
S(t)=\exp \left(-\lambda t^{p}\right)
$$

where $\lambda$ is parameterized $\lambda=\exp (X \beta)$ and $p$ is the ancillary parameter. $X$ contains several covariates that are expected to influence the retirement decision. Robust standard errors are adjusted for intragroup correlations across industries.

We also estimated models accounting for unobserved heterogeneity across industries and occupations by including a frailty term. We used several distributions for the frailty term. However, the results are not fundamentally different from the models without a correction for unobserved heterogeneity. 


\section{Results}

\subsection{Training and tenure}

Life cycle literature predicts that firm-specific training increases the demand for lower turnover and hence will stimulate tenure, so that firms can benefit from the rents resulting from the investment. Therefore, before we estimated the effects of training and technological change on retirement behavior, we first analyzed whether this assumption holds by estimating the correlation between training and tenure rates with OLS. The results of the OLS estimation are presented in Annex 1 and show that our indicator for a worker's firm-specific training history is significantly positively correlated with tenure. On the other hand a general training background is significantly negatively correlated with tenure. These results remain robust when adding occupation fixed effects and when accounting for selectivity.

\subsection{Training history and early retirement}

In Table 2 we first present the estimation results of the parametric hazard specification. ${ }^{13}$ Our estimation results in column 1 show that the human-capital variables affect workers' retirement behavior significantly in the way we expected. We find that older workers with a firm-specific training history have a significantly higher likelihood to retire earlier, while we do not find any effect of general training history on retirement behavior. This confirms our expectation that the provided pensions to workers with firm-specific skills enable early retirement.

Considering the results for the other variables, we can see that they are consistent with 
expectations. The likelihood of retirement increases with a worker's age and wage level. The coefficient of the health limitations variable is strongly significant and has a positive sign, indicating that workers with bad health have a larger likelihood to retire earlier. Workers with more years of schooling retire later. White older workers retire earlier. Government employees retire earlier than non-government employees. Work commitment has a significantly negative effect on the likelihood to retire. Marital status does not affect retirement behavior. The results for the technological change indicators deviate from the earlier findings of Bartel and Sicherman (1993). We do not find that gradual technological change and technological shocks have a significant effect on the likelihood of early retirement.

Columns 2 and 3 of Table 2 present the same analysis with industry dummy variables and interaction effects between technological shocks and our training indicators, respectively. As the table shows, including industry fixed effects does not lead to large deviations from our initial results. The interaction effects between technological shocks and the training indicators give an indication of the effects of stochastic changes in the value of marginal product on the labor market position of workers with firm-specific or general training. The coefficients of the interaction effects are not significant, suggesting that firms do not dispose of their older workers in case of an adverse shock in productivity. ${ }^{14}$

Insert Table 2 about here 


\subsection{Business cycle effects}

Both early-retirement incentives and our technological change indicators may be subject to disturbances caused by cyclical factors. Early-retirement incentives may be a consequence of mass layoffs and increased uncertainty resulting from a recession. Also, our technological change indicators are based on the productivity growth indicators of Jorgenson et al. (1987), which may not only include technological change, but also the utilization rate. Consequently, we control for fluctuations in the business cycle and include unemployment variables and output variables in our analysis.

The results of our analysis with the additional control variables for business cycle effects are presented in columns 1 and 2 of Table 3 . Column 1 shows the estimation results including the unemployment variable, while Column 2 contains the analysis with the output variables. The table shows that gradual output growth has a significant positive effect on the likelihood of early retirement while a high rate of unemployment has a significant negative effect. However, adding these control variables does not lead to large differences with our earlier findings. The firm-specific training history of workers remains to have a significant positive effect on the likelihood of retirement, indicating the robustness of our earlier findings.

Insert Table 3 about here

\subsection{Alternative training indicators}

Next, we constructed a training indicator which contains information on workers' pre1966 training participation as well as information on training participation after 1966. As 
the likelihood of causality problems (between training investments and retirement) rises with the use of training data after 1966, we only include the training incidence of workers younger than 53. The newly constructed training indicators are based on data in 1966, 1967, 1969, 1971, 1976 and 1981. The firm-specific training indicator now equals 1 if workers who are younger than 53 years participated in company-sponsored training and still benefit from this training in their present work. General training equals 1 if workers younger than 53 years responded that they participated in other forms of training. ${ }^{15}$

Table 4 presents the results of our analysis with our newly constructed training indicators. As the table shows, firm-specific training now only has a weak significant positive effect on the likelihood of retirement.

Insert Table 4 about here

\subsection{Job mobility, earning profiles and intermediate training forms}

It can be expected that especially workers who are covered by a pension scheme are less mobile across jobs. Therefore, we conducted an additional robustness analysis in which we corrected our initial training history indicators for job mobility, i.e. the firm-specific indicator is coded 0 for workers with a firm-specific training history who changed jobs after 1966. Table 5 gives the results of our analysis with the training history indicators, corrected for mobility. Column 1 shows the estimation results of a parametric model with the firm-specific training history indicator corrected for job mobility. As expected, the coefficient of the firm-specific training indicator is higher and more significant than the coefficient of our initial indicator. 
Secondly, we also corrected our general training history indicator for job mobility. The general training history indicator, corrected for job mobility, provides us with a proxy for 'transferable training forms'. As Stevens (1993) and Acemoglu and Pischke (1998) noted, when labor markets are imperfect and labor market frictions and institutions compress and distort the structure of wages, firms will also invest in the general skills of their employees. These studies relaxed the assumption of perfectly competitive labor markets that underlies human capital theory, and showed that firm-sponsored training arises as an equilibrium phenomenon. Apart from this prediction, contrasting with standard human capital theory, these studies showed that the distortion in the wage structure turns general skills into some intermediate form of skills which may have firm-specific value (transferable training). The key of the noncompetitive training model is the superior information of current employers regarding its employees' abilities relative to the information available for other firms, which creates ex post monopsony power. This leads to a situation in which trained workers with general skills are not paid their full marginal product when they change jobs, making general skills de facto specific, creating a situation in which firms and workers will share in the costs of both firm-specific training and general training. This makes firms also willing to provide upward sloping earning profiles to workers with general training. Therefore, it can be expected that due to deferred compensation, workers with an intermediate training background and still working in the same firm, retire earlier than workers with a general training history and working in another firm.

Column 2 of Table 5 give the results of our analysis in which both training indicators 
are corrected for job mobility. We now find that both the firm-specific training history indicator and the proxy for transferable training are positive and significant, although the size of the coefficient of the firm-specific training history indicator is larger. This confirms the expectation that firms also tend to decrease the level of turnover of workers with a general training background, on the condition that they have shared in the training costs. $^{16}$

Lastly, we conducted an analysis with interaction effects between training (corrected for mobility) and our indicator for technological shocks. The results are shown in column 3 of Table 5. Again, we do not find evidence that technological shocks lead to earlier retirement of workers with a firm-specific training background.

\section{Conclusion}

In this paper, we analyzed the relationship between workers' training investments in the beginning of their career and the probability of early retirement. The main finding is that workers with a firm-specific training background retire at an earlier age than workers with a general training background. This result remains significantly positive after controlling for technological change, work commitment, the effects of the business cycle and clustering of standard errors.

This indicates that shared investments in firm-specific training are embedded in implicit contracts that aim at decreasing turnover, but also restrict the retirement age. On the other hand, firms are less likely to enter into implicit contracts with workers who invested in general skills. 
The results presented in this paper are highly relevant for public policies that intend to increase labor force participation of older workers, which have become popular recently in industrialized countries that face the problems of an ageing population. As our study demonstrates, the effectiveness of institutional arrangements to postpone retirement will also depend on the training policies of firms.

\section{References}

Acemoglu, D., Pischke, J.-S., 1998. Why do firms train? theory and evidence. Quarterly Journal of Economics 113, 79-119.

Ashenfelter, O., Card, D., 2002. Did the elimination of mandatory retirement affect faculty retirement? American Economic Review 92, 957-980.

Bartel, A. P., Sicherman, N., 1993. Technological change and retirement decisions of older workers. Journal of Labor Economics 11 (1), 162-183.

Becker, G. S., 1975. Human Capital, 2nd Edition. Chicago: University of Chicago Press.

Bingley, P., Lanot, G., 2004. Employer pay policies, public transfers and the retirement decisions of men and women in denmark. European Economic Review 48 (1), 181-200.

Chan, S., Stevens, A. H., 2004. Do changes in pension incentives affect retirement? a longitudinal study of subjective retirement expectations. Journal of Public Economics 88, 1307-1333.

Dorsey, S., Macpherson, D. A., 1997. Pensions and training. Industrial Relations 36 (1), $81-96$. 
Fella, G., 2005. Termination restrictions and investment in general training. European Economic Review 49, 1480-1499.

Gustman, A. L., Mitchell, O. S., Steinmeier, T. L., 1994. The role of pensions in the labor market: a survey of the literature. Industrial and Labor Relations Review 47 (3), $417-438$.

Hashimoto, M., 1981. Firm-specific human capital as a shared investment. American Economic Review 71, 475-482.

Johnson, R. W., 1996. The impact of human capital investments on pension benefits. Journal of Labor Economics 14 (3), 520-554.

Jorgenson, D. W., Gollop, F. M., Fraumeni, B., 1987. Productivity and US Economic Growth. Cambridge: Harvard University Press.

Kennan, J., 1979. Bonding and the enforcement of labor contracts. Economic Letters 3, $61-66$.

Lazear, E. P., Moore, R. L., 1984. Incentives, productivity and labor contracts. Quantitative Journal of Economics 99, 275-295.

Samwick, A. A., 1998. New evidence on pensions: Social security, and the timing of retirement. NBER Working paper, 6534.

Smith, S. P., 1991. Ending mandatory retirement in the arts and sciences. American Economic Review 82 (2), 106-110. 
Stevens, M., 1994. A theoretical model of on-the-job training with imperfect competition. Oxford Economic Papers 46 (4), 537-562.

Stock, J. H., Wise, D. A., 1990. Pensions, the option value of work, and retirement. Econometrica 58 (5), 1151-1180.

Williamson, S. H., 1995. The development of industrial pensions in the united states in the twentieth century. World Bank Policy Research Working Paper 1542. 
Table 1

Descriptive statistics

\begin{tabular}{lrrrrr}
\hline \hline & Min & Max & Mean & Std. Dev. & $\begin{array}{r}\text { Dummy: \% } \\
\text { Obs. coded 1 }\end{array}$ \\
\hline Retirement & 0 & 1 & & & 48.80 \\
Firm-specific training & 0 & 1 & & & 4.08 \\
General training & 0 & 1 & & .012 & 18.74 \\
Gradual technological change & -.145 & .034 & .006 & 1.37 & \\
Technological shocks & -4.05 & 4.86 & -.173 & & 31.59 \\
Race & 0 & 1 & & & \\
Marital status & 0 & 1 & & & \\
Years of schooling & 0 & 18.00 & 9.24 & 3.90 & 19.84 \\
Tenure & 0 & 67.00 & 15.04 & 12.10 & \\
Health limitations & 0 & 1 & & & \\
If government employee & 0 & 1 & & & \\
Self-employed & 0 & 1 & & & \\
Age & 45.00 & 59.00 & 51.50 & 4.27 & \\
Commitment to work & 0 & 1 & & & \\
Unemployment & 3.50 & 9.60 & 6.57 & 1.84 & \\
Output growth & -.038 & .265 & .037 & .020 & \\
Output shock & -5.25 & 15.35 & -.049 & 3.07 & \\
Wage level & 33.51 & $50,000.00$ & $6,276.18$ & $4,407.11$ & \\
\hline \hline
\end{tabular}

$\mathrm{N}=4,549$. In the Table, we give the percentage of workers who retired between 1966 and 1983 Observations are censored after the first retirement or until individuals dropped out of the survey. The firm-specific training and general training indicators are based on the question asked in 1966 whether workers had ever received formal training. Gradual technological change is the mean of yearly rates of industrial productivity change based on Jorgenson et al. (1987). The variable which measures unexpected technological shocks is defined as a z-score. The table gives the mean years of schooling. Output growth and outputs shocks are calculated analogous to our gradual technological change and technological shock indicators. The wage level is converted to constant 1966 dollars. 
Table 2

Weibull regression results: Retirement, training history and technological change (robust standard errors in parentheses)

\begin{tabular}{|c|c|c|c|}
\hline Dependent variable: Retirement & $(1)$ & $(2)$ & $(3)$ \\
\hline \multirow[t]{2}{*}{ Constant } & -22.594 & -23.764 & -23.769 \\
\hline & $(1.067)^{* * *}$ & $(1.170)^{* * *}$ & $(1.165)^{* * *}$ \\
\hline \multirow[t]{2}{*}{ Firm-specific training } & .285 & .239 & .238 \\
\hline & $(.090)^{* * *}$ & $(.084)^{* * *}$ & $(.085)^{* * *}$ \\
\hline \multirow[t]{2}{*}{ General training } & .038 & .035 & .029 \\
\hline & $(.064)$ & $(.064)$ & $(.061)$ \\
\hline \multirow[t]{2}{*}{ Gradual technological change } & .012 & .139 & .140 \\
\hline & $(.044)$ & $(.104)$ & $(.104)$ \\
\hline \multirow[t]{2}{*}{ Technological shocks } & .032 & .012 & .019 \\
\hline & $(.035)$ & $(.029)$ & $(.034)$ \\
\hline \multirow[t]{2}{*}{ Int. technological shocks and firm-specific training } & & & .051 \\
\hline & & & $(.129)$ \\
\hline \multirow[t]{2}{*}{ Int. technological shocks and general training } & & & -.038 \\
\hline & & & $(.032)$ \\
\hline \multirow[t]{2}{*}{ Race } & -.167 & -.182 & -.182 \\
\hline & $(.051)^{* * *}$ & $(.054)^{* * *}$ & $(.054)^{* * *}$ \\
\hline \multirow[t]{2}{*}{ Marital status } & -.063 & -.061 & -.059 \\
\hline & $(.080)$ & $(.077)$ & $(.078)$ \\
\hline \multirow[t]{2}{*}{ Years of schooling } & -.046 & -.035 & -.043 \\
\hline & $(.007)^{* * *}$ & $(.007)^{* * *}$ & $(.007)^{* * *}$ \\
\hline \multirow[t]{2}{*}{ Health limitations } & .660 & .647 & .649 \\
\hline & $(.039)^{* * *}$ & $(.039)^{* * *}$ & $(.039)^{* * *}$ \\
\hline \multirow[t]{2}{*}{ If government employee } & .209 & .438 & .436 \\
\hline & $(.093)^{* *}$ & $(.127)^{* * *}$ & $(.127)^{* * *}$ \\
\hline \multirow[t]{2}{*}{ Age } & .205 & .219 & .219 \\
\hline & $(.013)^{* * *}$ & $(.016)^{* * *}$ & $(.016)^{* * *}$ \\
\hline \multirow[t]{2}{*}{ Commitment to work } & -.462 & -.411 & -.411 \\
\hline & $(.039)^{* * *}$ & $(.047)^{* * *}$ & $(.048)^{* * *}$ \\
\hline \multirow[t]{2}{*}{ Log wage } & .319 & .221 & .221 \\
\hline & $(.051)^{* * *}$ & $(.048)^{* * *}$ & $(.048)^{* * *}$ \\
\hline \multicolumn{2}{|l|}{ Industry dummy variables } & included & included \\
\hline \multirow[t]{2}{*}{$1 / \mathrm{p}$} & .266 & .253 & .253 \\
\hline & $(.008)^{* * *}$ & $(.008)^{* * *}$ & $(.008)^{* * *}$ \\
\hline Log-Likelihood & -971.87 & -892.83 & -892.33 \\
\hline $\mathrm{N}$ & 3,696 & 3,696 & 3,696 \\
\hline
\end{tabular}

$* * *<0.01, * *<0.05, *<0.10$. 
Table 3

Weibull regression results: Retirement, training history and technological change, controlled for business cycle effects (robust standard errors in parentheses)

\begin{tabular}{|c|c|c|}
\hline Dependent variable: Retirement & $(1)$ & $(2)$ \\
\hline \multirow[t]{2}{*}{ Constant } & -23.545 & -24.401 \\
\hline & $(1.171)^{* * *}$ & $(1.099)^{* * *}$ \\
\hline \multirow[t]{2}{*}{ Firm-specific training } & .251 & .253 \\
\hline & $(.083)^{* * *}$ & $(.085)^{* * *}$ \\
\hline \multirow[t]{2}{*}{ General training } & .043 & .044 \\
\hline & $(.063)$ & $(.064)$ \\
\hline \multirow[t]{2}{*}{ Gradual technological change } & .124 & .105 \\
\hline & $(.086)$ & $(.069)$ \\
\hline \multirow[t]{2}{*}{ Technological shocks } & .024 & .016 \\
\hline & $(.026)$ & $(.021)$ \\
\hline \multirow[t]{2}{*}{ Race } & -.186 & -.182 \\
\hline & $(.054)^{* * *}$ & $(.054)^{* * *}$ \\
\hline \multirow[t]{2}{*}{ Marital status } & -.060 & -.054 \\
\hline & $(.079)$ & $(.078)$ \\
\hline \multirow[t]{2}{*}{ Years of schooling } & -.034 & -.034 \\
\hline & $(.007)^{* * *}$ & $(.007)^{* * *}$ \\
\hline \multirow[t]{2}{*}{ Health Limitations } & .644 & .646 \\
\hline & $(.040)^{* * *}$ & $(.039)^{* * *}$ \\
\hline \multirow[t]{2}{*}{ If government employee } & .435 & .431 \\
\hline & $(.126)^{* * *}$ & $(.127)^{* * *}$ \\
\hline \multirow[t]{2}{*}{ Age } & .219 & .218 \\
\hline & $(.016)^{* * *}$ & $(.016)^{* * *}$ \\
\hline \multirow[t]{2}{*}{ Commitment to work } & -.410 & -.409 \\
\hline & $(.047)^{* * *}$ & $(.047)^{* * *}$ \\
\hline \multirow[t]{2}{*}{ Log wage } & .220 & .221 \\
\hline & $(.047)^{* * *}$ & $(.050)^{* * *}$ \\
\hline \multirow[t]{2}{*}{ Unemployment } & -.103 & \\
\hline & $(.017)^{* * *}$ & \\
\hline \multirow[t]{2}{*}{ Gradual output change } & & .126 \\
\hline & & $(.058)^{* *}$ \\
\hline \multirow[t]{2}{*}{ Output shocks } & & .022 \\
\hline & & $(.018)$ \\
\hline Industry dummy variables & included & included \\
\hline \multirow[t]{2}{*}{$1 / \mathrm{p}$} & .241 & .241 \\
\hline & $(.007)^{* * *}$ & $(.007)^{* * *}$ \\
\hline Log-Likelihood & -881.62 & -882.87 \\
\hline $\mathrm{N}$ & 3,696 & 3,696 \\
\hline
\end{tabular}

$* * *<0.01, * *<0.05, *<0.10$. 
Table 4

Weibull regression results: Retirement, training (including training incidence after 1966) and technological change (robust standard errors in parentheses)

\begin{tabular}{|c|c|c|}
\hline Dependent variable: Retirement & (1) & $(2)$ \\
\hline \multirow[t]{2}{*}{ Constant } & -24.593 & -24.596 \\
\hline & $(1.084)^{* * *}$ & $(1.082)^{* * *}$ \\
\hline \multirow[t]{2}{*}{ Firm-specific training } & .178 & .177 \\
\hline & $(.104)^{*}$ & $(.103)^{*}$ \\
\hline \multirow[t]{2}{*}{ General training } & .086 & .084 \\
\hline & $(.086)$ & $(.083)$ \\
\hline \multirow[t]{2}{*}{ Gradual technological change } & .098 & .098 \\
\hline & $(.071)$ & $(.070)$ \\
\hline \multirow[t]{2}{*}{ Technological shocks } & .017 & .022 \\
\hline & $(.021)$ & $(.025)$ \\
\hline \multirow[t]{2}{*}{ Int. technological shocks and firm-specific training } & & .074 \\
\hline & & $(.143)$ \\
\hline \multirow[t]{2}{*}{ Int. technological shocks and general training } & & -.042 \\
\hline & & $(.036)$ \\
\hline \multirow[t]{2}{*}{ Race } & -.186 & -.186 \\
\hline & $(.054)^{* * *}$ & $(.054)^{* * *}$ \\
\hline \multirow[t]{2}{*}{ Marital status } & -.054 & -.053 \\
\hline & $(.077)$ & $(.078)$ \\
\hline \multirow[t]{2}{*}{ Years of schooling } & -.035 & -.035 \\
\hline & $(.007)^{* * *}$ & $(.006)^{* * *}$ \\
\hline \multirow[t]{2}{*}{ Health Limitations } & .641 & .643 \\
\hline & $(.039)^{* * *}$ & $(.039)^{* * *}$ \\
\hline \multirow[t]{2}{*}{ If government employee } & .431 & .429 \\
\hline & $(.125)^{* * *}$ & $(.125)^{* * *}$ \\
\hline \multirow[t]{2}{*}{ Age } & .222 & .222 \\
\hline & $(.016)^{* * *}$ & $(.016)^{* * *}$ \\
\hline \multirow[t]{2}{*}{ Commitment to work } & -.414 & -.415 \\
\hline & $(.048)^{* * *}$ & $(.048)^{* * *}$ \\
\hline \multirow[t]{2}{*}{ Log wage } & .219 & .219 \\
\hline & $(.051)^{* * *}$ & $(.051)^{* * *}$ \\
\hline \multirow[t]{2}{*}{ Gradual output change } & .127 & .128 \\
\hline & $(.059)^{* *}$ & $(.058)^{* *}$ \\
\hline \multirow[t]{2}{*}{ Output shocks } & .021 & .021 \\
\hline & $(019)$ & $(.019)$ \\
\hline Industry dummy variables & included & included \\
\hline \multirow[t]{2}{*}{$1 / \mathrm{p}$} & .242 & .242 \\
\hline & $(.009)^{* * *}$ & $(.009)^{* * *}$ \\
\hline Log-Likelihood & -882.88 & -882.45 \\
\hline $\mathrm{N}$ & 3,696 & 3,696 \\
\hline
\end{tabular}


$* * *<0.01, * *<0.05, *<0.10$. The constructed training indicators are based on data in 1966, 1967, 1969, 1971, 1976 and 1981. The firm-specific training indicator equals 1 if workers younger than 53 years responded that they had received compony sponsored training and still benefit from this training in their present work. General training equals 1 if workers younger than 53 years responded to have received other forms of training. Although this additional analysis takes the training incidence after 1966 into account, we do not use training information of workers who were older than 52 years in 1966. As our training history indicators measure if workers ever received training, we may lose potentially useful information. Moreover, the likelihood of causality problems rises with the use of training data after 1966. 
Table 5

Weibull regression results: Retirement, training history and technological change, corrected for mobility and business cycle effects (robust standards errors in parentheses)

\begin{tabular}{|c|c|c|c|}
\hline Dependent variable: Retirement & $(1)$ & $(2)$ & $(3)$ \\
\hline \multirow[t]{2}{*}{ Constant } & -24.379 & -24.322 & -24.333 \\
\hline & $(1.096)^{* * *}$ & $(1.078)^{* * *}$ & $(1.070)^{* * *}$ \\
\hline Firm-specific training & .378 & .444 & .444 \\
\hline (corrected for mobility) & $(.119)^{* * *}$ & $(.121)^{* * *}$ & $(.121)^{* * *}$ \\
\hline \multirow[t]{2}{*}{ General training } & .046 & & \\
\hline & $(.064)$ & & \\
\hline General training & & .338 & .333 \\
\hline (corrected for mobility) & & $(.069)^{* * *}$ & $(.069)^{* * *}$ \\
\hline \multirow[t]{2}{*}{ Gradual technological change } & .104 & .103 & .103 \\
\hline & $(.069)$ & $(.069)$ & $(.069)$ \\
\hline \multirow[t]{2}{*}{ Technological shocks } & .015 & .016 & .019 \\
\hline & $(.021)$ & $(.021)$ & $(.025)$ \\
\hline Int. technological shocks and firm-specific training & & & .089 \\
\hline (corrected for mobility) & & & $(.121)$ \\
\hline Int. technological shocks and general training & & & -.029 \\
\hline (corrected for mobility) & & & $(.052)$ \\
\hline \multirow[t]{2}{*}{ Race } & -.182 & -.168 & -1.68 \\
\hline & $(.054)^{* * *}$ & $(.052)^{* * *}$ & $(.052)^{* * *}$ \\
\hline \multirow[t]{2}{*}{ Marital status } & -.056 & -.051 & -.051 \\
\hline & $(.077)$ & $(.076)$ & $(.077)$ \\
\hline \multirow[t]{2}{*}{ Years of schooling } & -.035 & -.038 & -.038 \\
\hline & $(.007)^{* * *}$ & $(.007)^{* * *}$ & $(.007)^{* * *}$ \\
\hline \multirow[t]{2}{*}{ Health Limitations } & .643 & .656 & .657 \\
\hline & $(.040)^{* * *}$ & $(.041)^{* * *}$ & $(.041)^{* * *}$ \\
\hline \multirow[t]{2}{*}{ If government employee } & .434 & .439 & .439 \\
\hline & $(.126)^{* * *}$ & $(.121)^{* * *}$ & $(.121)^{* * *}$ \\
\hline \multirow[t]{2}{*}{ Age } & .218 & .217 & .217 \\
\hline & $(.016)^{* * *}$ & $(.016)^{* * *}$ & $(.016)^{* * *}$ \\
\hline \multirow[t]{2}{*}{ Commitment to work } & -.416 & -.426 & -.427 \\
\hline & $(.048)^{* * *}$ & $(.050)^{* * *}$ & $(.049)^{* * *}$ \\
\hline \multirow[t]{2}{*}{ Log wage } & .219 & .207 & .208 \\
\hline & $(.050)^{* * *}$ & $(.048)^{* * *}$ & $(.047)^{* * *}$ \\
\hline \multirow[t]{2}{*}{ Gradual output change } & .127 & .131 & .131 \\
\hline & $(0.58)^{* *}$ & $(0.58)^{* *}$ & $(0.58)^{* *}$ \\
\hline \multirow[t]{2}{*}{ Output shocks } & .021 & .021 & .022 \\
\hline & $(.018)$ & $(.019)$ & $(.019)$ \\
\hline Industry dummy variables & included & included & included \\
\hline \multirow[t]{2}{*}{$1 / \mathrm{p}$} & .241 & .240 & .240 \\
\hline & $(.009)^{* * *}$ & $(.009)^{* * *}$ & $(.004)^{* * *}$ \\
\hline Log-Likelihood & -881.28 & -870.41 & -869.94 \\
\hline $\mathrm{N}$ & 3,696 & 3,696 & 3,696 \\
\hline
\end{tabular}


$* * *<0.01, * *<0.05, *<0.10$. The training-history indicators are corrected for job mobility. The indicators are coded 0 for workers (with a training history in their previous job) who left their initial job after 1966 . 


\section{Annex 1}

Table A2.1

OLS Regression results: Tenure and training (robust standard errors in parentheses)

\begin{tabular}{|c|c|c|c|}
\hline Dependent variable: Tenure & (1) & (2) & (3) \\
\hline \multirow[t]{2}{*}{ Constant } & -81.724 & -78.597 & -54.390 \\
\hline & $(7.774)^{* * *}$ & $(7.709)^{* * *}$ & $(11.130)^{* * *}$ \\
\hline \multirow[t]{2}{*}{ Firm-specific training } & 1.379 & 1.598 & 1.538 \\
\hline & $(.424)^{* * *}$ & $(.421)^{* * *}$ & $(.421)^{* * *}$ \\
\hline \multirow[t]{2}{*}{ General training } & -.615 & -.472 & -.514 \\
\hline & $(.215)^{* * *}$ & $(.218)^{* * *}$ & $(.217)^{* *}$ \\
\hline \multirow[t]{2}{*}{ Gradual technological change } & .087 & .153 & \\
\hline & $(.078)$ & $(.078)^{* *}$ & \\
\hline \multirow[t]{2}{*}{ Technological shocks } & .027 & .041 & \\
\hline & $(.058)$ & $(.058)$ & \\
\hline \multirow[t]{2}{*}{ Race } & 1.893 & 2.075 & 2.130 \\
\hline & $(.200)^{* * *}$ & $(.203)^{* * *}$ & $(.205)^{* * *}$ \\
\hline \multirow[t]{2}{*}{ Marital status } & 1.311 & 1.118 & 1.105 \\
\hline & $(.257)^{* * *}$ & $(.255)^{* * *}$ & $(.254)^{* * *}$ \\
\hline \multirow[t]{2}{*}{ Years of schooling } & -.067 & -.084 & -.121 \\
\hline & $(.026)^{* *}$ & $(.029)^{* * *}$ & $(.030)^{* * *}$ \\
\hline \multirow[t]{2}{*}{ Health limitations } & -.430 & -.383 & .638 \\
\hline & $(.197)^{* *}$ & $(.194)^{* *}$ & $(389)$ \\
\hline \multirow[t]{2}{*}{ If government employee } & -1.108 & -.879 & -.901 \\
\hline & $(.207)^{* * *}$ & $(.214)^{* * *}$ & $(.214)^{* * *}$ \\
\hline \multirow[t]{2}{*}{ Age } & 1.436 & 1.361 & .253 \\
\hline & $(.275)^{* * *}$ & $(.272)^{* * *}$ & $(.426)$ \\
\hline \multirow[t]{2}{*}{ Age2 } & -.010 & -.009 & .002 \\
\hline & $(.002)^{* * *}$ & $(.002)^{* * *}$ & $(.004)$ \\
\hline \multirow[t]{2}{*}{ Log wage } & 5.464 & 5.271 & 5.626 \\
\hline & $(.1287)^{* * *}$ & $(.133)^{* * *}$ & $(.132)^{* * *}$ \\
\hline \multirow[t]{2}{*}{ IMR } & & & -4.502 \\
\hline & & & $(1.480)^{* * *}$ \\
\hline Year dummy variables & included & included & included \\
\hline Occupatation dummy variables & & included & included \\
\hline Adjusted R-square & .132 & .152 & \\
\hline Observations & 17,837 & 17,837 & 24,249 \\
\hline
\end{tabular}

$* * *<0.01, * *<0.05, *<0.10$. Independent variables in first stage: year of schooling, age age squared, race, health limitations, gradual technological change, technological shocks. 


\section{Notes}

${ }^{1}$ Due to the tax preferred status of pensions and the progressivity of income taxes, many workers prefer company sponsored pension plans to upward sloping earning profiles(Gustman et al., 1994).

${ }^{2}$ The firm pays a wage that is lower than the value of their marginal product. Because workers with firm-specific skills are more productive in their present firm than in other firms, the wage after a firmspecific investment will still be higher than the wage earned elsewhere. Rent sharing from firm-specific training investments is discussed by Hashimoto (1981). In the context of a risk of a layoff or quit, the central focus of the model developed by Hashimoto is that worker productivity is costly to evaluate. Firms only know the current productivity of the workers they employ, while workers know their potential productivity. In the presence of such information costs, firms and workers will share the returns to firm-specific training in order to minimize the loss of separation.

${ }^{3}$ Other explanations for incentives for long-term employment relationships are given by Lazear (1979) and Lazear and Moore (1984) who argue that to encourage employees to be trustworthy (and not to shirk), long tenure incentives should be created. Another reason is that long-term employment relationships reduce the transaction costs that accompany recruitment and hiring. Moreover, employers have more information on the ability of their own employees than on prospective employees, which enables them to offer long tenures to their most productive workers (Johnson, 1996).

${ }^{4}$ Moreover, Chan and Stevens (2004) found that the effect is overestimated when no controls for unobserved heterogeneity are made.

${ }^{5}$ It should be noticed that the distinction between general and firm specific training is based on strong theoretical assumptions. Although it may be relevant to loosen these assumptions by introducing imperfect competition in our analysis (see Stevens, 1994; Acemoglu and Piscke, 1998), the database used for our empirical analysis contains no information on firm or sector characteristics. However, by correcting the general training indicator for job mobility in our robustness analysis, we are able to indirectly analyze the effect of transferable forms of training on the likelihood of early retirement.

${ }^{6}$ Also, workers who reported a wage below 100 dollar are excluded from our analysis. This reduces our sample to 4,549 men.

${ }^{7}$ The institutional mandatory retirement age was 65 until approximately 1979. After 1979, the institutional mandatory retirement age shifted to 70 years. The shift in the institutional mandatory retirement age is not visible in our database due to the fact that a substantial number of workers retired before 1980. However, there exists a large literature on the abolishment of mandatory retirement in the US, due to the stepwise amendments of the Federal Age Discrimination in Employment Act (ADEA). The ADEA was passed in 1967, and protected all workers aged between 40 and 65 from discrimination in hiring, firing and promotion on the basis of age. The first amendments in 1978 led to the shift in the mandatory retirement age in 1979, when the enforcement of these amendments intensified. After 1986 mandatory retirement has been forbidden. Most studies find that the end of mandatory retirement led to an increase in the retirement age, indicating that workers are indeed motivated to work longer due to backward loading earning profiles (e.g. Smith, 1991, Ashenfelter and Card, 2002).

${ }^{8}$ When considering the relationship between training and retirement of workers at the end of their career, it is hard to establish causality. Workers may anticipate retirement and base the decision to train on the expected retirement age. Therefore, we do not use the information on training behavior after 1966.

${ }^{9}$ The specific training indicator equals 0 for workers who trained in the past, but do not use this training in the current job. 
${ }^{10}$ As technological change variables such as research and development intensity and the extent of computer usage are not available for all industry sectors, we have to use the indirect measures of Jorgenson et al. (1987).

${ }^{11}$ On the condition that the wealth effect dominates the substitution effect between earnings and leisure.

${ }^{12}$ The Weibull distribution is suitable for modelling data with monotonous hazard rates that either increase $(p>1)$ or decrease with time $(p<1)$.

$131 / \mathrm{p}$ is positive, smaller than 1 and significant at the $1 \%$ level, which indicates that the hazard of failure (retirement) increases with time.

${ }^{14}$ However, due to the imperfect measurement of training and due to the fact that we do not observe productivity on an individual level, we cannot draw direct conclusions from these results

${ }^{15}$ Although this additional analysis takes the training incidence after 1966 into account, we did not use training information of workers who were older than 52 years in 1966, because of potential causality problems. As our training history indicators only measure whether workers ever received training, we now lose potential useful information for workers older than 52 who did train before 1966 .

${ }^{16}$ However, cautioun is necessary when interpreting these results, as workers who are still working in the same firm may have distinct characteristics which influence the retirement decision. 